\title{
CELEBRATING THE 50TH VOLUME OF STUDIA BOTANICA HUNGARICA
}

Studia botanica hungarica was founded in 1961 by the museologists of the Botanical Department of the Hungarian Natural History Museum. The scientific journal published its 50th volume in 2019. The first issues (Vols 1-7) had been titled as Fragmenta Botanica and it was renamed in 1973.

The original scope of this botanical journal was to publish enumerations from the collections of the Botanical Department. The main aim was to report taxonomic, floristical, and ecological works of the museologists of the Botanical Department. Nowadays, the journal is open for all scientists, and publishes articles from all fields of botany and mycology. The main focus of the published papers is still on systematical and floristical research of the Carpathian Basin and the Balkan Peninsula. The recent aim of the editorial board is to continuously improve the journal quality following high level international standards.

Conventionally, a staff member of the Botanical Department was appointed as the editor-in-chief of Studia botanica hungarica: J. Ujhelyi (Vols 1-7), G. Fekete (Vols 8-10), S. Orbán (Vol. 11), Zs. P. Komáromy (Vols 12-17), L. Hably (Vols 1823), L . Lőkös (Vols 24-28), B. Papp (Vols 29-45), and Z. Barina (from Vol. 46). The editorial board (Vols 5-32, "adiuvantibus"), invited also from the staff (G. Bohus, Z. K. Dobolyi, G, Fekete, L. Hably, M. Járai-Komlódi, D. Kováts, Cs. Locsmándi, F. Németh, Zs. P.-Komáromy, K. P. Verseghy, I. Rácz, M. Rajczy, L. Somlyay, J. Sz. Lacza, T. A. Szabó, J. Ujhelyi), carried out the reviewing of the manuscripts. From Vol. 33 various experts have been requested for peer-reviewing, and in addition, a new editorial board was also established from Vol. 45 (A. Alegro, Z. Barina, K. Buczkó, B. Erdei, L. Hably, D. Lakušić, L. Lőkös, B. Papp, I. Rácz, M. Shevera, E. Szurdoki). A technical editor is also participating in the process (Cs. Locsmándi for Vols 24-26, L. Lőkös for Vols 20-23, 27-).

The first issue was published 58 years ago, however there were some years without published issues or with two volumes published together; since 2001 it appears in every year. Since 2014 two issues have been published annually.

Altogether 58 issues were published including two supplement volumes containing altogether 428 papers on 7,500 pages. 299 authors, among them 40 staff members of the museum, published 11 necrologies, 13 papers on the field of history of science, 150 on vascular plants, 37 algological, 101 bryological, 53 mycological, 34 lichenological, 21 palaeobotanical and 8 other papers. Several hundreds of floristical novelties (or other results) have been reported in various floristical (and other) papers, predominantly from Hungary and the Carpathian-Balkan regions, and mainly from the following countries: Albania, Armenia, Bulgaria, Cameroon, 
Croatia, Czech Republic, Estonia, Georgia (Abkhazia), Greece, India, Japan, Mexico, Mongolia, North Korea, North Macedonia, Pakistan, Portugal, Republic of Moldova, Romania, Serbia, Slovakia, South Korea, Turkey, Ukraine, and Vietnam.

Highlighting the considerable scientific impact of the journal 49 taxa (34 species, 4 varieties, 11 forms) new for the science were described in Studia botanica bungarica volumes. Among the described taxa almost all plant groups were represented; 1 alga (Chara hellenica Langangen), 1 bryophyte (Radula camerunensis Pócs et Döbbeler), 24 vascular plants (Chamaecytisus korabensis Pifkó et Barina, Ch. pseudojankae Pifkó et Barina, Hedera $\times$ schmidtii M. Bényei-Himmer, $H$. $\times$ soroksarensis M. Bényei-Himmer et $\mathrm{M}$. Höhn, $H$. crebrescens $\mathrm{M}$. Bényei-Himmer et M. Höhn, Juniperus phoenicea L. f. prostrata Debreczy et Rácz, Koeleria javorkae Ujhelyi, Saxifraga cymosa W. et K. f. dichotoma Pócs, S. moschata Wulf. var. integra Pócs, Sorbus concavifolia Cs. Németh, S. pelsoensis Cs. Németh, S. pyricarpa Cs. Németh, $S$. rhombiformis Barabits et Cs. Németh, S. vallusensis Cs. Németh, Tilia $\times$ praelustris Wagn. ex Vöröss, $T . \times$ pseudopulchra Wagn. ex Vöröss, T. argentea Desf. var. colurnifolia Borb. f. subglobularis Wagn. ex Vöröss, T. caucasica Rupr. var. angulata Rupr. f. seiunctobracteata Vöröss, T. euchlora C. Koch f. pseudo-multibracteata Vöröss, T. grandifolia Ehrh. var. copiosa Wagn. f. praestabilis Wagn. ex Vöröss, $T$. platyphyllos Scop. var. aenobarba (Borb.) Jáv. f. pseudo-trichogyna Vöröss, T. platyphyllos Scop. var. tenuifolia (Host.) Simk. f. grandibracteata Vöröss, T. platyphyllos Scop. var. tenuifolia (Host.) Simk. f. sublaevigata Wagn. ex Vöröss, T. pseudolongirostris Wagn. ex Vöröss), 4 fossil plants (Bacutriletes ajkaensis Rákosi et Barbacka, Phyllites skofleki Hably, Ptilophyllum maculatum Givulescu, Spermatites kaptalanfaensis Rákosi et Barbacka). Besides of plants description of new 9 fungi taxa (Agaricus campester (L.) Fr. var. xanthodermatoides Bohus, Collybia distorta (Fr.) Quél. var. amara Babos, Coprinus micaceus (Bull.) Fr. var. mammosus Babos, Inocybe aeruginascens Babos, Lepista irinoides Bohus, Leucopaxillus paradoxus (Cost.Dufour) Bours. f. subaerugineus Bohus, Pluteus nigroviridis Babos, Triadelphia morgoensis Révay, Tricholoma nodulosporum Babos et Bohus) and 10 lichens (Agrestia zerovii S. Y. Kondr., A. B. Gromakova et Khodos., Aspicilia pseudoabbasiana S. Y. Kondr., L. Lőkös et J.-S. Hur, A . pseudovulcanica S. Y. Kondr., L. Lőkös et J.-S. Hur, A. subepiglypta S. Y. Kondr., L. Lökös et J.-S. Hur, A. subgeographica S. Y. Kondr., L. Lőkös et J.-S. Hur, A. subgoettweigensis S. Y. Kondr., L. Lőkös et J.-S. Hur, A. submamillata S. Y. Kondr., L. Lőkös et J.-S. Hur, Caloplaca vitellinoides Vers., Lecanora albomarginata (Nyl.) Cromb. f. arundinicola Gallé, Phaeophyscia esslingeri S. Y. Kondr., L. Lőkös, J.-J. Woo et J.-S. Hur) were also published.

In the past six decades there were many modifications in our botanical journal, some of these reflected changing expectations of Hungarian and international publishing standards. At an early stage articles were officially accepted in Hungarian, English, German, French or Russian, although there were no 

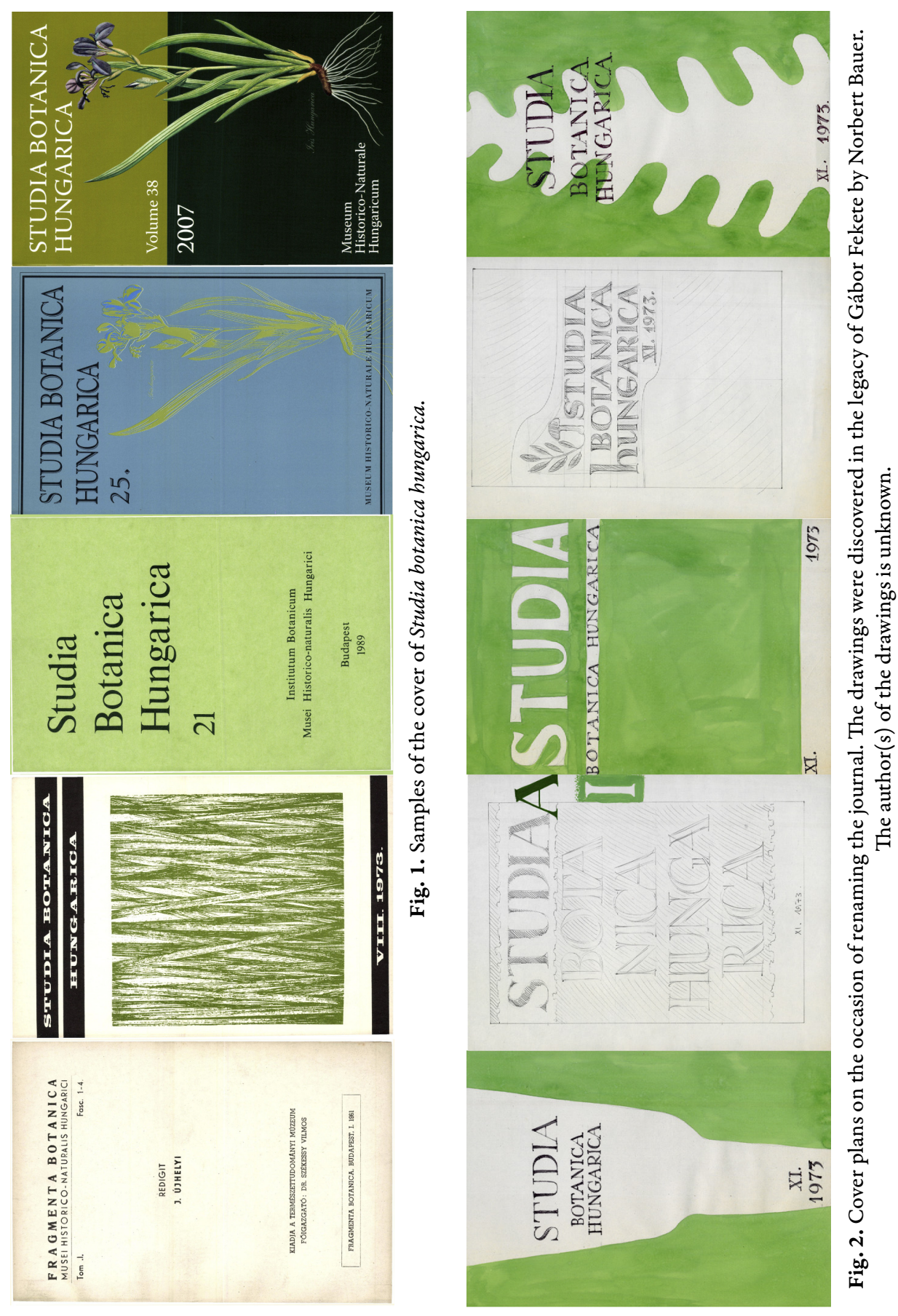
papers submitted in Russian language. Originally, the Abstract was written in Hungarian when the main text was in English, German or French, but if the paper was written in Hungarian the Abstract was in English, German or French. Since 1994 (Vol. 25) the preferable language of papers including the Abstract has been English. Linguistic quality of the papers was checked and improved by various lectors (mainly from museum colleagues): P. Csontos, B. Erdei (from Vol. 46-), T. Fuisz, I. Rácz (Vols 29-45), I. Téringer, T. Vásárhelyi, L. Zombori.

Rotaprint offset printing technique was performed for volumes 1-22 by different printing companies (Magyar Nemzeti Múzeum Rotaprint/Múzeumok Rotaüzeme, Népművelési Propaganda Iroda sokszorosító/Népművelési Propaganda Iroda nyomdája/Múzsák Közművelődési Kiadó nyomdája). Digital desk top publishing was put into practice by L. Peregovits (Pars Kft.) from volume 23. Printing preparation was provided by Corel Ventura (L. Peregovits for Vols 23-37, and then É. Hajdú for Vols 38-43), later by Adobe InDesign (L. Lőkös from Vol. 44), using Palatino Linotype (Font Kft.) typeset (for Vols 23-37), then Garamond Premier Pro (Font Kft.) typeset (from Vol. 38). Volumes (from Vol. 23) were printed by the following printing companies: B32 Nyomda Kft., Központi Múzeumi Igazgatóság nyomdája, Nagy-Gáspár Kft., Mondat Ltd., Prospektkop Bt., Winterfair Ltd.

The cover of the journal has also changed four times (Fig. 1). The first change was in 1973, when Fragmenta Botanica was renamed Studia botanica hungarica. Between 1989 and 1993 a simple green cover changed the earlier design of Zs. Bunke. The blue cover with Iris hungarica W. et K. drawing was used between 1994 and 2006. The recent cover was promoted in 2007. The latter two were designed by the Tüzvonal Grafikai Stúdió (Budapest).

In the legacy of Gábor Fekete we found some original plans of the cover (Fig. 2 ) intended for the first issue of the renamed journal. However, none of them came true, they clearly showed the engagement of earlier staff members to this journal.

Now Studia botanica hungarica is also availabe online (http://publication. nhmus.hu/studbot/bannales.php). The DOI numbers for papers were introduced from the 46th volume (2015). Individual papers are also available online in pdf format from the following repository: https://library.hungaricana.hu/hu/collection/ muze_orsz_ttud_studia_botanica_hungarica/

Following the legacy of our predecessors, the mission of the current editorial board is to provide the continuous publication of the issues and to improve the scientific quality and publishing style. We hope this journal will continue to provide a possibility to publish botanical researches from the Carpathian and Balkan region.

Erzsébet SzURDOKI

Head of the Botanical Department Hungarian Natural History Museum 